\title{
Antioxidant and Anti Aging Assays of Oryza Sativa Extracts, Vanillin and Coumaric Acid
}

\author{
Wahyu Widowati ${ }^{1 *}$, Nurul Fauziah ${ }^{1}$, Heddy Herdiman ${ }^{1}$, Merry Afni ${ }^{2}$, Ervi Afifah ${ }^{2}$, Hanna Sari \\ W. Kusuma ${ }^{2}$, Hayatun Nufus ${ }^{2}$, Seila Arumwardana ${ }^{2}$ and Dwi Davidson Rihibiha ${ }^{2}$ \\ ${ }^{1}$ Medical Research Center, Faculty of Medicine, Maranatha Christian University, Jl Prof Drg Surya \\ Sumantri No 65 Bandung 40164, West Java, Indonesia \\ ${ }^{2}$ Aretha Medika Utama, Biomolecular and Biomedical Research Center, Jl Babakan Jeruk 2, \\ No 9, Bandung 40163, West Java, Indonesia
}

\section{Abstract}

Aging is a natural process in humans as accumulation of oxygen-derived free radicals which leads to the activation of hyaluronidase, collagenase and elastase, that can further contribute to cellular and tissue damage. Bioactive compounds from plants have been used as antioxidant that might inhibit aging processes as well. This study aimed to determine antioxidant and anti aging properties of Oryza sativa Extract (OSE), and its compounds, vanillin and coumaric acid. The phytochemical analysis of OSE was performed with Farnsworth modified method. Antioxidant activities were performed by measurement of 2,2-diphenyl 1-pichylhydazyl (DPPH) free radical scavenger, Ferric Reducing Antioxidant Power (FRAP), and 2,2'-azino-bis (3-ethylbenzothiazoline-6-sulphonic acid) (ABTS) reducing activity, while anti aging assay were observed through inhibitory of elastase, collagenase, and hyaluronidase activities. Phytochemical analysis showed the presence of terpenoids and saponins in high level. OSE showed lowest DPPH activity $\left(I_{50}=314.51 \mu \mathrm{g} /\right.$ $\mathrm{mL}$ ) compared to vanillin $\left(I C_{50}=283 \mu \mathrm{g} / \mathrm{mL}\right)$ and coumaric acid $\left(\mathrm{IC}_{50}=255.69 \mu \mathrm{g} / \mathrm{mL}\right)$. In ABTS assay, OSE resulted lowest activity $\left(I C_{50}=145.67 \mu \mathrm{g} / \mathrm{mL}\right)$, compared to vanillin $\left(\mathrm{IC}_{50}=4.96 \mu \mathrm{g} / \mathrm{mL}\right)$ and coumaric acid $\left(\mathrm{IC}_{50}=1.67 \mu \mathrm{g} /\right.$ $\mathrm{mL})$. OSE also showed the lowest FRAP activity $(21.26 \mu \mathrm{M} \mathrm{Fe}(\mathrm{II}) / \mu \mathrm{g})$, compared to vanillin $(35.05 \mu \mathrm{M} \mathrm{Fe}(\mathrm{II}) / \mu \mathrm{g})$ and coumaric acid $(48.52 \mu \mathrm{M} \mathrm{Fe}(\mathrm{II}) / \mu \mathrm{g})$. OSE showed the lowest collagenase, elastase, and hyaluronidase inhibitory activities $\left(\mathrm{IC}_{50}=816.78,107.51\right.$, and $\left.203.13 \mu \mathrm{g} / \mathrm{mL}\right)$, compared to vanillin $\left(\mathrm{IC}_{50}=16.27,14.46,45.23 \mu \mathrm{g} / \mathrm{mL}\right.$ respectively) and coumaric acid $\left(\mathrm{IC}_{50}=146.89,25.38,8.21 \mu \mathrm{g} / \mathrm{mL}\right.$ respectively). In summary, OSE possess the lowest antioxidant and anti aging activities compared to vanillin and coumaric acid.

Keywords: Antioxidant, Anti aging, Coumaric Acid, Oryza sativa, Vanillin

\section{Introduction}

Skin aging is the natural process due to photo aging by environmental factors such as chronic UV radiation. The repetitive exposure to UV radiation cause accelerated physical changes in the skin and connective tissue through the formation of lipid peroxides, the cell contents and Reactive Oxygen Species (ROS) ${ }^{1}$. It leads to loss of skin elasticity implicated in formation of wrinkle, uneven pigmentation, brown spots, laxity and leathery appearance, solar elastosis, actinic purpura, precancerous lesions, skin cancer, and melanoma ${ }^{2-4}$.

During aging process, collagen, elastin, and hyaluronic acid decrease, that causes loss of strength and flexibility in the skin, resulting in visible wrinkles. It is also related to increasing enzymes activity including

\footnotetext{
${ }^{*}$ Author for correspondence

Email: wahyu_w60@yahoo.com
} 
collagenase, elastase and hyaluronidase. Collagenase is known as an enzyme that plays role in the degradation of collagen. Collagen is the main component with percentage of $70-80 \%$ of the total skin weight, the increasing degradation of collagen is significant in the photo aging process ${ }^{5,6}$. Hyaluronan or hyaluronic acid is one of important components of the tissue matrix substance and has a role in the development, growth, and repair of damaged tissue ${ }^{6}$. Meanwhile, elastin play a role in the maintenance of skin elasticity, but elastase can degrade it ${ }^{7}$. Degradation of the Extracellular Matrix (ECM) has been directly linked to skin aging and is correlated with an increase in activity of certain enzymes involved in skin aging ${ }^{8,9}$. Inhibition of these enzymes is crucial in anti aging prevention ${ }^{10}$.

It has been reported that skin aging occurs in the presence of cumulative endogenous damage due to Reactive Oxygen Species (ROS) ${ }^{11}$. ROS are defined as oxygen-containing, highly reactive species. ROS are generated constantly during normal cellular metabolism which is essential for biological functions. Excessive ROS causes oxidative stress and damage of biological molecules ${ }^{12,13}$. Previous studies have investigated that continuous ROS exposure can stimulate skin aging through antioxidant system destruction, wrinkle formation, and melanogenesis ${ }^{12}$. ROS are usually eliminated from the body through antioxidant defense system $^{14}$. Thus, maintaining antioxidant homeostasis is an appropriate strategy to prevent skin aging.
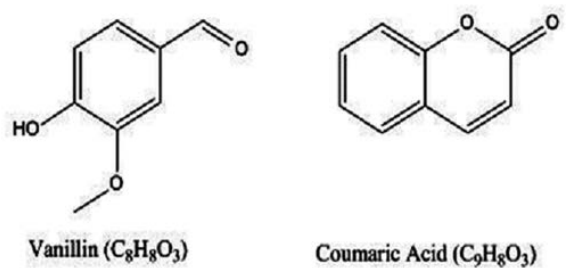

Coumaric Acid $\left(\mathrm{C}_{9} \mathrm{H}_{8} \mathrm{O}_{3}\right)$

Fig. 1. Chemical structure of vanillin and coumaric acid.

Antioxidant properties derived from natural sources have been proposed for aging prevention ${ }^{15}$. Bioactive compounds contained in plants such as isoflavones, anthocyanins, and catechins may have promising antioxidant activity against $\mathrm{ROS}^{16}$. Oryza sativa L. is one of the most produced and consumed cereals in the world that contain phenolic compounds, tocopherols, tocotrienols, and g-oryzanol. Phenolic acids were identified in the lignin fraction of rice bran (O. sativa) such as caffeic, chlorogenic, p-coumaric, ferulic, gallicacids, p-hydroxybenzoic, protocatechuic, syringic and vanillin ${ }^{17-19}$. Vanillin and coumaric acid have antioxidants activity that can inhibit aging processes ${ }^{20,21}$. In the present study, free radical scavenging activity of O. sativa Extract (OSE) and its compounds, vanillin and coumaric acid (Figure 1) were evaluated as well as inhibitory activities of collagenase, elastase, and hyaluronidase.

\section{Materials and Methods}

\subsection{Preparation of O. sativa Extracts}

The plants of $O$. sativa were collected from the plantation in Ciherang, Subang, West Java. The plants were identified by herbarium staff, Department of Biology, School of Life Science and Technology, Bandung Institute of Technology, Bandung, West Java, Indonesia. The grain of $O$. sativa (600 g) were mashed, extracted using distilled ethanol $70 \%(2,750 \mathrm{~mL})$ by a maceration method. Every $24 \mathrm{~h}$ the ethanol was filtered and the wastes were re-macerated in triplicate. The ethanol filtrate collected was condensed using $50^{\circ} \mathrm{C}$ rota vapor to obtain OSE. The extract in pasta form $(5.64 \mathrm{~g})$ was stored at $-20{ }^{\circ} \mathrm{C}$, and used for further assay ${ }^{22}$. Standards compounds used in this study were vanillin with $99 \%$ purity [Sigma V1104, USA] and coumaric acid (CA) with $98 \%$ purity [Biopurify Phytochemical 14111707, China].

\subsection{Qualitative Phytochemical Screening Assay}

The phytochemical assay was conducted on O. sativa Extracts (OSE) using modified Farnsworth method to qualitatively identify presence of phenols, steroid/ triterpenoids, saponins, tannins, terpenoids, flavonoids, and alkaloids as listed below ${ }^{23-25}$.

\subsubsection{Phenol Identification}

Around $10 \mathrm{mg}$ of sample was placed on a dropping plate, then $1 \% \mathrm{FeCl}_{3}$ [Merck 1.03861.0250, USA] was added 
into the sample. The color formation of green/red/ purple/blue/black shows presence of phenol ${ }^{23-25}$.

\subsubsection{Steroid/Triterpenoid Identification}

Approximately $10 \mathrm{mg}$ of sample was placed on a dropping plate, then soaked with acetate acid until the sample was covered. After 10-15 min, one drop of absolute sulfate acid $\left(\mathrm{H}_{2} \mathrm{SO}_{4}\right)$ [Merck 109073, USA] was added to the sample. The formation of green/blue color indicates the presence of steroid while red/orange sediment indicates the presence of triterpenoid ${ }^{23-25}$.

\subsubsection{Saponin Identification}

Approximately $10 \mathrm{mg}$ of sample was put into the test tube with some water and boiled for $5 \mathrm{~min}$. It was shaken vigorously and saponin content was indicated by persistence of froth on the surface ${ }^{23-25}$.

\subsubsection{Tannin Identification}

Approximately $10 \mathrm{mg}$ of samples was added with $2 \mathrm{~mL}$ of $\mathrm{HCl} 2 \mathrm{~N}$ [Merck 1003171000] in the test tube, then heated on a the water bath for $30 \mathrm{~min}$. The mixture was cooled down and filtered, the filtrate was added with amyl alcohol [Merck 10979, USA]. Purple colour formation indicates positive reaction for tannins ${ }^{23-25}$.

\subsubsection{Terpenoid Identification}

Around $10 \mathrm{mg}$ of sample was added into a dropping plate, then vanillin and $\mathrm{H}_{2} \mathrm{SO}_{4}$ was added to the sample. Terpenoid presence was indicated by the formation of purple color on the mixture ${ }^{23-25}$.

\subsubsection{Flavonoid Identification}

About $10 \mathrm{mg}$ of sample was added into a test tube, then $\mathrm{Mg}$ [Merck EM105815, USA] and $\mathrm{HCl} 2 \mathrm{~N}$ was added to the sample. The mixture sample was heated for 5 to 10 min, then filtered after it was cooled down. Subsequently, amyl alcohol was added into the filtrate. The positive reaction was shown by the formation of red or orange color $^{23-25}$.

\subsubsection{Alkaloid Identification}

The small amount of sample (10 mg) was introduced into a test tube, then $10 \%$ ammonia was added into the sample. After chloroform added to the mixture, two layers of liquid was formed and the bottom layer was collected. $\mathrm{HCl} 1 \mathrm{~N}$ was added to the liquid, forming two layers. The upper layer collected and added with 1-2 drops of Draggendorf solution. The presence of yellow colour indicated positive result ${ }^{23-25}$.

\subsection{2,2-Diphenyl-1-picrylhydrazil (DPPH) Assay}

The DPPH assay was conducted using the method from Widowati et al., study ${ }^{26}$. The method is based on the reduction of alcoholic DPPH solution in the presence of a hydrogen-donating antioxidant due to the formation of the non-radical 2,2-diphenyl-1-picrylhydrazine $(\mathrm{DPPH}-\mathrm{H})^{27}$. Briefly, $50 \mu \mathrm{L}$ of various level of samples (50-400 $\mu \mathrm{g} / \mathrm{mL}$ for extract and $50-400 \mu \mathrm{M}$ for compounds in the DMSO) were added to each well in a 96-well micro plate. It was then followed by addition of $200 \mu \mathrm{l}$ of 2,2-Diphenyl-1-picrylhydrazil (DPPH) [Sigma D9132, USA] solution $(0.077 \mathrm{mmol} / \mathrm{L}$ in methanol) into the well. The mixture was then incubated in the dark for $30 \mathrm{~min}$ at room temperature. Afterward, the absorbance was read using a microplate reader (Multiskan ${ }^{\mathrm{Tm}}$ GO Microplate Spectrophotometer, Thermo Scientific, Waltham, MA, USA) at $517 \mathrm{~nm}$ wave length. The radical scavenging activity was measured using the following formula:

$$
\% \text { Scavenging }=(\mathrm{Ac}-\mathrm{As}) / \mathrm{Ac} \times 100
$$

$\mathrm{Ac}=$ negative control absorbance (without sample).

As = sample absorbance.

\subsection{ABTS-Reducing Activity Assay}

The antioxidant capacity of OSE, vanillin, and CA were measured using 2,2'-Azinobis-(3-ethylbenzothiazoline-6-sulfonic acid) $\left(\mathrm{ABTS}^{\bullet+}\right)$ [Sigma A1888-2G, USA] diammonium salt-free radical assay ${ }^{28}$. ABTS $^{-+}$ solution was produced by reacting $14 \mathrm{mM}$ ABTS and $4.9 \mathrm{mM}$ potassium persulfate [Merck EM105091, USA] (1:1 volume ratio) for $16 \mathrm{~h}$ in dark condition at room temperature, then the mixture was diluted with 5.5 $\mathrm{mM}$ PBS (pH 7.4) until the absorbance of the solution was $0.70 \pm 0.02$ at wavelength $745 \mathrm{~nm}$. In brief, $2 \mu \mathrm{l}$ of various level of samples were added to each well at 96-well microplate, then to the samples the fresh 198 $\mu$ ABTS $^{\bullet+}$ solution were added. The absorbance was 
measured at $745 \mathrm{~nm}$ after the plate incubated for $6 \mathrm{~min}$ at $30^{\circ} \mathrm{C}$. The percentage inhibition of ABTS radical (\%) was determined by the ratio of reducing of $\mathrm{ABTS}^{*}$ absorbance in the presence of the sample relative to the absorbance in the absence of the sample (negative control). The median Inhibitory Concentration $\left(\mathrm{IC}_{50}\right)$ were also calculated ${ }^{28,29}$.

\subsection{Ferric Reducing Antioxidant Power (FRAP) Assay}

The Ferric Reducing Antioxidant Power Assay (FRAP) was estimated using modified method from Mishra et al., and Widowati ${ }^{28,30}$. The FRAP reagent was prepared freshly by mixing $10 \mathrm{~mL}$ of acetate buffer $300 \mathrm{mM}, 1 \mathrm{~mL}$ of ferric chloride hexahydrate [Merck 1.03943.0250, USA] $20 \mathrm{mM}$ dissolved in distilled water, and $1 \mathrm{~mL}$ of 2,4,6-Tris(2-pyridyl)-s-triazine (TPTZ) [Sigma 368235-7, USA] $10 \mathrm{mM}$ dissolved in $\mathrm{HCl} 40 \mathrm{mM}$. In 96-well micro plate, $7.5 \mu \mathrm{l}$ of various level of samples (12.5-100 $\mu \mathrm{g} / \mathrm{mL}$ for OSE and 12.5-100 $\mu \mathrm{M}$ for compounds) were mixed with $142.5 \mu \mathrm{L}$ FRAP reagent then incubated for $30 \mathrm{~min}$ at $37^{\circ} \mathrm{C}$. The absorbance value was measured at $593 \mathrm{~nm}$ with a micro plate reader. The standard curve was made using $\mathrm{FeSO}_{4}$, between 0.019 and $95 \mu \mathrm{g} / \mathrm{mL}$ $\mathrm{FeSO}_{4}$. The results of samples were expressed in $\mu \mathrm{M} \mathrm{Fe}$ (II)/ $\mu$ g extract ${ }^{28}$.

\subsection{Collagenase Inhibitory Activity Assay}

Collagenase inhibitory activity was measured according to modified method of Sigma-Aldrich dan Thring et $a l^{7}$. Mixed solution included $10 \mu \mathrm{L}$ Collagenase from Clostridium histolyticum [Sigma C8051, USA] (0.01 U/ $\mathrm{mLin}$ the cool aquades), $60 \mu \mathrm{L}$ Tricine buffer $(50 \mathrm{mM}, \mathrm{pH}$ 7.5 , content of $10 \mathrm{mM} \mathrm{CaCl}_{2}$ dan $\left.400 \mathrm{mM} \mathrm{NaCl}\right), 30 \mu \mathrm{L}$ of various level of sample $(0-250 \mu \mathrm{g} / \mathrm{mL}$ for OSE and 0-250 $\mu \mathrm{M}$ for compounds in the DMSO), then incubated at $37^{\circ} \mathrm{C}$ for $20 \mathrm{~min}$. After incubated added $20 \mu \mathrm{L} \mathrm{N}$-[3-(2Furyl)acryloyl]-leu-gly-Pro-Ala [Sigma F5135, USA] (1 $\mathrm{mM}$ in theTricine buffer) substrate. Absorbance was measured at $335 \mathrm{~nm}$ wave length.

\footnotetext{
$\%$ Collagenase inhibition $=(1-B / A) \times 100 \%$

$\mathrm{A}=$ sample absorbance

$\mathrm{B}=$ control absorbance
}

\subsection{Elastase Inhibitory Activity Assay}

Elastase inhibitory activity was measured by modified method of Sigma Aldrich and Thring et $a l^{7}$. A mixture of $10 \mu$ Lof various level of samples $(0-66.67 \mu \mathrm{g} / \mathrm{mL}$ for OSE and $0-66.67 \mu \mathrm{M}$ for compounds), $5 \mu \mathrm{L}$ elastase from porcine pancreas [Sigma 45124, USA] $(0.5 \mathrm{mU} /$ $\mathrm{mL}$ in the cool aquades) and $125 \mu \mathrm{L}$ Tris buffer was preincubated for $15 \mathrm{~min}$ at $25^{\circ} \mathrm{C}$. Mixed solution was added $\mathrm{N}$-Sucanyl-Ala-Ala-Ala-p-Nitroanilide substrate [Sigma 54760, USA] and then incubated for $15 \mathrm{~min}$ at $25^{\circ} \mathrm{C}$. Absorbance was measured by $410 \mathrm{~nm}$ wavelengths.

$$
\begin{aligned}
& \% \text { Elastase inhibition }=(1-\mathrm{B} / \mathrm{A}) \times 100 \% \\
& \mathrm{~A}=\text { sample absorbance } \\
& \mathrm{B}=\text { control absorbance }
\end{aligned}
$$

\subsection{Hyaluronidase Inhibitory Activity Assay}

Hyaluronidase inhibitory of activity was measured by modified method of Sigma Aldrich and Tu and Tawata ${ }^{31}$. A mix of $25 \mu \mathrm{L}$ of various level of samples $(0-166.67 \mu \mathrm{g} /$ $\mathrm{mL}$ for OSE and $0-166.67 \mu \mathrm{M}$ for compounds) and $3 \mu \mathrm{L}$ hyaluronidase from bovine testes type I-S [Sigma H3506, USA] was pre-incubated for $10 \mathrm{~min}$ at $37^{\circ} \mathrm{C}$ and then added $12 \mu \mathrm{L}$ phosphate buffer $(300 \mathrm{mM}, \mathrm{pH} 5.35)$ for 10 min at $37^{\circ} \mathrm{C}$. Afterward $10 \mu \mathrm{L}$ hyaluronic acid substrate [Sigma H5542, USA] was added and incubated for 45 min at $37^{\circ} \mathrm{C}$. Decomposition reaction of hyaluronic acid was stopped by adding $100 \mu \mathrm{L}$ acidic albumin acid. Mixed solution incubated at room temperature for $10 \mathrm{~min}$, then absorbance was measured at $600 \mathrm{~nm}$ wavelengths.
Quantification of inhibition activity by formula:
$\%$ Hyaluronidase inhibition $=(1-\mathrm{B} / \mathrm{A}) \times 100 \%$
$\mathrm{A}=$ sample absorbance
$\mathrm{B}=$ control absorbance

\section{Results}

\subsection{Phytochemical Screening of OSE}

Phytochemical screening of the plants showed the presence of phenols, flavonoids, terpenoids, saponins, 
tannins and alkaloids. The result of OSE phytochemical screening can be seen in Table 1 .

Table 1: The result of qualitative phytochemical screening of OSE

\begin{tabular}{lc}
\hline Phytochemical content & OSE \\
\hline Phenols & + \\
Steroids/Triterpenoids & $-/+$ \\
Terpenoids & +++ \\
Saponins & +++ \\
Flavonoids & - \\
Tannins & - \\
Alkaloids & - \\
\hline
\end{tabular}

${ }^{*}++++$ : very high content; $+++:$ high content; $++:$ moderate content; + : low content; - : not detected

Phytochemical screening of OSE aimed to detect presence of phenols, steroids, saponins, flavonoids, and tannins in OSE. Terpenoids and saponins was detected in high content $(+++)$, phenols and triterpenoids were low content $(+)$, while steroids, flavonoids, tannins and alkaloids were not detected (-) (Table 1).

\subsection{2,2-Diphenyl-1-picrylhydrazil (DPPH) Assay}

$\mathrm{DPPH}$ is a reagent for investigating the free radical scavenging activities of compounds. In the $\mathrm{DPPH}$ test, the extracts were able to reduce the stable radical DPPH to the yellow coloured diphenylpicrylhydrazine $(\mathrm{DPPH}-\mathrm{H})^{32,33}$. The percentage of DPPH scavenging activity of OSE, vanillin, and coumaric acid can be seen in Figure 2 and the median Inhibitory Concentration $\left(\mathrm{IC}_{50}\right)$ of samples toward DPPH free radical scavenging activity can be seen in Table 2 .

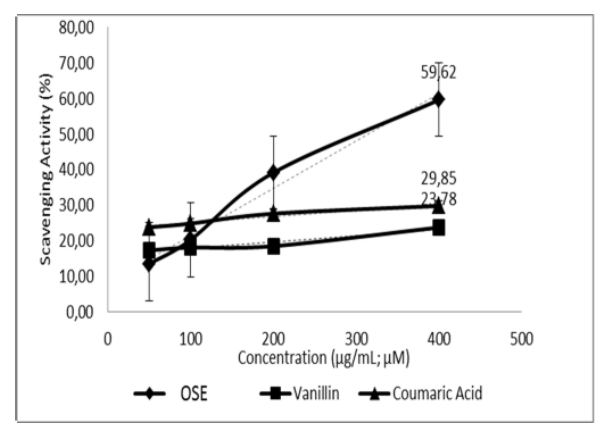

Fig. 2. DPPH scavenging activity of OSE, vanillin, and coumaric acid. OSE, vanillin, and coumaric acid were diluted in DMSO to reach the final concentration of $50.00 ; 100.00$; $200.00 ; 400.00(\mu \mathrm{g} / \mathrm{mL} ; \mu \mathrm{M})$.
Table 2: $I C_{50}$ value DPPH scavenging activity of OSE, vanillin, and coumaric acid

\begin{tabular}{lcccc}
\hline Samples & Equation & $\mathbf{R}^{2}$ & $\mathbf{I C}_{50}(\mu \mathrm{M})$ & $\mathbf{I C}_{50}(\mu \mathrm{g} / \mathrm{mL})$ \\
\hline OSE & $\mathrm{Y}=0.13 x+8.36$ & 0.98 & - & 314.51 \\
Vanillin & $\mathrm{Y}=0.02 \mathrm{x}+16.05$ & 0.93 & 1865.16 & 283.76 \\
Coumaric & $\mathrm{Y}=0.02 \mathrm{x}+23.36$ & 0.95 & 1557.78 & 255.69 \\
Acid & & & & \\
\hline
\end{tabular}

${ }^{\star}$ Linear equations, coefficient of regression $\left(\mathrm{R}^{2}\right)$ and $\mathrm{IC}_{50}$ of each sample were calculated. $\mathrm{IC}_{50}$ of OSE was presented in $\mu \mathrm{g} / \mathrm{mL}$, while vanillin and coumaric acid were presented in $\mu \mathrm{M}$ and $\mu \mathrm{g} / \mathrm{mL}$.

Based on Figure 2, DPPH radical scavenging activity was concentration-dependent manner, in which higher concentration increased DPPH scavenging activity. At the highest concentration $(400 \mu \mathrm{g} / \mathrm{mL})$, OSE has the highest DPPH scavenging activity compared to vanillin and coumaric acid $(59.62 \pm 5.81 \%, 23.86 \pm 0.57 \%$, and $17.39 \pm 0.16 \%$, respectively) (Figure 2). However, $\mathrm{IC}_{50}$ value of coumaric acid has the lowest value $(255.69 \mu \mathrm{g} /$ $\mathrm{mL})$ compared to OSE $(314.51 \mu \mathrm{g} / \mathrm{mL})$ and vanillin $(283.76 \mu \mathrm{g} / \mathrm{mL})$ (Table 2). These results indicate OSE has low DPPH-scavenging activity among treatments.

\subsection{ABTS - Reducing Activity Assay}

ABTS-reducing activity assay measures the relative ability of antioxidant to scavenge the ABTS generated. The ABTS is generated by reacting a strong oxidizing agent (potassium permanganate/potassium persulfate) with the ABTS salt. Reduction of blue-green ABTS radical colored solution by hydrogen-donating antioxidant is measured by the long wave absorption spectrum ${ }^{34}$. The result ABTS-reducing activity of OSE, vanillin, and coumaric acid based on $\mathrm{IC}_{50}$ value can be seen in Table 3 .

Table 3: IC $\mathrm{C}_{50}$ value ABTS-reducing activity of OSE, vanillin, and coumaric acid

\begin{tabular}{lcccc}
\hline Samples & Equation & $\mathbf{R}^{2}$ & $\mathbf{I C}_{50}(\mu \mathrm{M})$ & $\mathbf{I C}_{50}(\mu \mathrm{g} / \mathrm{mL})$ \\
\hline OSE & $\mathrm{Y}=0.33 \mathrm{x}+2.41$ & 0.99 & & 145.67 \\
Vanillin & $\mathrm{Y}=1.39 \mathrm{x}+4.72$ & 0.99 & 32.63 & 4.96 \\
Coumaric & $\mathrm{Y}=3.17 \mathrm{x}+17.76$ & 0.95 & 10.18 & 1.67 \\
Acid & & & & \\
\hline
\end{tabular}

${ }^{*}$ Linear equations, coefficient of regression $\left(\mathrm{R}^{2}\right)$ and $\mathrm{IC}_{50}$ of each sample were calculated. $\mathrm{IC}_{50}$ of OSE was presented in $\mu \mathrm{g} / \mathrm{mL}$, while vanillin and coumaric acid were presented in $\mu \mathrm{M}$ and $\mu \mathrm{g} / \mathrm{mL}$. 
The antioxidant activity of OSE, vanillin, and coumaric acid were evaluated by ABTS-reducing activity assay. The $\mathrm{IC}_{50}$ of ABTS-reducing activity of OSE, vanillin, and coumaric acid can be seen in Table 3. OSE has the lowest ABTS-reducing activity as indicated by highest $\mathrm{IC}_{50}(145.67 \mu \mathrm{g} / \mathrm{mL})$ compared to vanillin $(4.96 \mu \mathrm{g} / \mathrm{mL})$ and coumaric acid $(1.67 \mu \mathrm{g} / \mathrm{mL})$. The result indicated OSE has weak activity antioxidant compared to these compounds.

\subsection{Ferric Reducing Antioxidant Power (FRAP) Assay}

The Ferric Reducing Antioxidant Power (FRAP) method is based on the reduction of a ferroin analog, the $\mathrm{Fe}^{3+}$ complex of tripyridyltriazine $\mathrm{Fe}(\mathrm{TPTZ})^{3+}$ to the intensely blue coloured $\mathrm{Fe}^{2+}$ complex $\mathrm{Fe}(\mathrm{TPTZ})^{2+}$ by antioxidants in acidic medium. Absorbance of Fe(II) complex at 593 $\mathrm{nm}$ produced by antioxidant reduction of corresponding tripyridyltriazine $\mathrm{Fe}(\mathrm{III})$ complex $^{35}$. FRAP activity of OSE, vanillin, and coumaric acid can be seen in Figure 3.

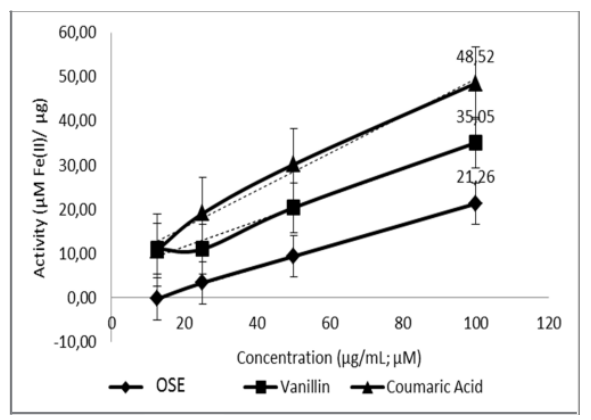

Fig. 3. FRAP Activity of OSE, vanillin, and coumaric acid. OSE, vanillin, and coumaric acid were diluted in DMSO to reach the final concentration of $12.50 ; 25.00 ; 50.00 ; 100.00$ $(\mu \mathrm{g} / \mathrm{mL} ; \mu \mathrm{M})$.

The result of the present study showed FRAP activity in concentration-dependent manner, in which higher concentration increased FRAP activity (Figure 3). At the highest concentration $(100 \mu \mathrm{g} / \mathrm{mL})$ OSE has a lowest FRAP with value $(21.26 \pm 0.21 \mu \mathrm{M} \mathrm{Fe}(\mathrm{II}) / \mu \mathrm{g})$ compared to vanillin $(35.05 \pm 0.80 \mu \mathrm{M} \mathrm{Fe}(\mathrm{II}) / \mu \mathrm{g})$ and coumaric acid $(48.52 \pm 0.24 \mu \mathrm{M} \mathrm{Fe}(\mathrm{II}) / \mu \mathrm{g})$. That indicates OSE has the lowest antioxidant activity in the FRAP assay compared to vanillin and coumaric acid.

\subsection{Collagenase Inhibitory Activity}

A spectrophotometric method was used to collagenase activity assay, and to detect potential collagenase inhibitor ${ }^{36}$. The collagenase inhibitory activity of OSE, vanillin, and coumaric acid can be seen in Figure 4 .

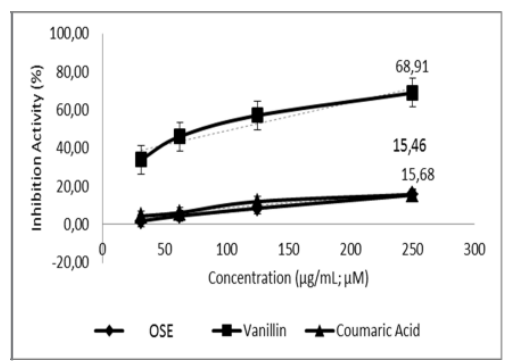

Fig. 4. Collagenase inhibitory activity of OSE, vanillin and coumaric acid. OSE, vanillin, and coumaric acid were diluted in DMSO to reach the final concentration of 31.25; $62.50 ; 125.00 ; 250.00(\mu \mathrm{g} / \mathrm{mL} ; \mu M)$.

Collagenase inhibitory activity of OSE, vanillin, and coumaric acid based on $\mathrm{IC}_{50}$ value can be seen in Table 4 .

Table 4: $I C_{50}$ value collagenase inhibitory activity of OSE, vanillin, and coumaric acid

\begin{tabular}{lcccc}
\hline Samples & Equation & $\mathbf{R}^{2}$ & $\mathbf{I C}_{50}(\mu \mathrm{M})$ & $\mathbf{I C}_{50}(\mu \mathrm{g} / \mathrm{mL})$ \\
\hline OSE & $\mathrm{y}=0.06 \mathrm{x}+0.42$ & 0.99 & - & 816.78 \\
Vanillin & $\mathrm{y}=0.15 \mathrm{x}+34.16$ & 0.92 & 106.99 & 16.27 \\
Coumaric & $\mathrm{y}=0.05 \mathrm{x}+3.47$ & 0.93 & 894.83 & 146.89 \\
Acid & & & & \\
\hline
\end{tabular}

${ }^{*}$ Linear equations, coefficient of regression $\left(\mathrm{R}^{2}\right)$ and $\mathrm{IC}_{50}$ of each sample were calculated. $\mathrm{IC}_{50}$ of OSE was presented in $\mu \mathrm{g} / \mathrm{mL}$, while vanillin and coumaric acid were presented in $\mu \mathrm{M}$ and $\mu \mathrm{g} / \mathrm{mL}$.

Figure 4 shows collagenase activities of OSE coumaric acid and vanillin in concentration-dependent manner. Collagenase activities of OSE (15.46 $\pm 1.12 \%)$ and coumaric acid $(15.68 \pm 1.67 \%)$ were comparable, but lower than vanillin $(68.91 \pm 1.56 \%)$. However, $\mathrm{IC}_{50}$ value of OSE was the highest $(816.78 \mu \mathrm{g} / \mathrm{mL})$ compared to coumaric acid $(146.89 \mu \mathrm{g} / \mathrm{mL})$ and vanillin $(16.27 \mu \mathrm{g} /$ $\mathrm{mL}$ ) (Table 4). These findings indicate OSE has very low collagenase inhibitory activity, compared to coumaric acid and vanillin.

\subsection{Elastase Inhibitory Activity}

The elastase inhibitory activity of OSE, vanillin and coumaric acid were measured. The percentation elastase 
inhibitory activity of OSE, vanillin and coumaric acid can be seen in Figure 5.

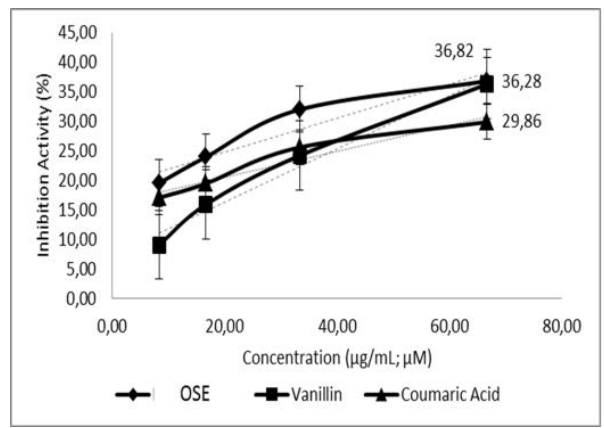

Fig. 5. Elastase inhibitory activity of OSE, vanillin, and coumaric acid. OSE, vanillin, and coumaric acid were diluted in DMSO to reach the final concentration of $8.33 ; 16.67$; $33.33 ; 66.67(\mu \mathrm{g} / \mathrm{mL} ; \mu \mathrm{M})$.

The $\mathrm{IC}_{50}$ value an elastase inhibitory activity of OSE, vanillin, and coumaric acid based on $\mathrm{IC}_{50}$ value can be seen in Table 5.

Table 5: IC $C_{50}$ value elastase inhibitory activity of OSE, vanillin, and coumaric acid

\begin{tabular}{lcccc}
\hline Samples & Equation & $\mathbf{R}^{2}$ & $\mathbf{I C}_{50}(\mu \mathrm{M})$ & $\mathbf{I C}_{50}(\mu \mathrm{g} / \mathrm{mL})$ \\
\hline OSE & $\mathrm{Y}=0.29 \mathrm{x}+19.07$ & 0.91 & - & 107.51 \\
Vanillin & $\mathrm{Y}=0.45 \mathrm{x}+7.31$ & 0.98 & 95.07 & 14.46 \\
Coumaric & $\mathrm{Y}=0.22 \mathrm{x}+16.13$ & 0.94 & 154.66 & 25.38
\end{tabular}

Acid

${ }^{*}$ Linear equations, coefficient of regression $\left(\mathrm{R}^{2}\right)$ and $\mathrm{IC}_{50}$ of each sample were calculated. $\mathrm{IC}_{50}$ of OSE was presented in $\mu \mathrm{g} / \mathrm{mL}$, while vanillin and coumaric acid were presented in $\mu \mathrm{M}$ and $\mu \mathrm{g} / \mathrm{mL}$.

Elastase inhibitory activity of OSE, vanillin, and coumaric acid showed the highest inhibition percentage at the highest concentration $(36.82 \pm 0.40 \%, 36.28 \pm$ $0.20 \%, 29.86 \pm 0.45 \%$ respectively) (Figure 5). However, vanillin showed the highest activity in elastase inhibition with $\mathrm{IC}_{50}$ value $14.46 \mu \mathrm{g} / \mathrm{mL}$. OSE and coumaric acid have $\mathrm{IC}_{50}$ value $107.62 \mu \mathrm{g} / \mathrm{mL}$ and $25.38 \mu \mathrm{g} / \mathrm{mL}$, respectively (Table 5). The result showed that OSE posses low elastase inhibition compared to vanillin and coumaric acid.

\subsection{Hyaluronidase Inhibitory Activity}

Hyaluronidase was assayed by a highly sensitive spectrophotometric method, based on precipitation of HA with cetylpyridinium chloride, which is used for high throughout screening for hyaluronidase inhibitors ${ }^{37}$.
Hyaluronidase inhibitory activity can be used to evaluate anti aging activity of OSE, vanillin, coumaric acid. The percentation hyaluronidase inhibition activity of OSE, vanillin, and coumaric acid can be seen in Figure 6.

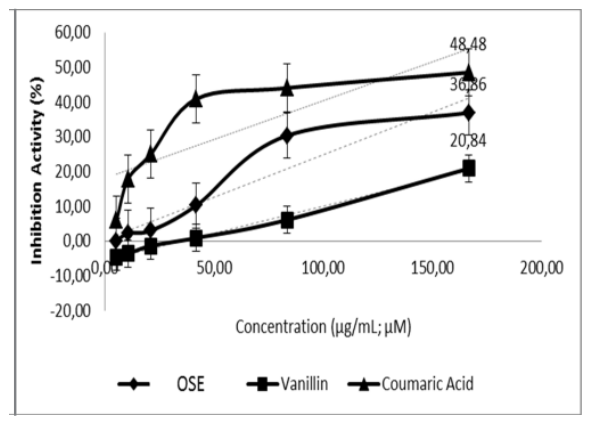

Fig. 6. Hyaluronidase inhibitory activity of OSE, vanillin, and coumaric acid. OSE, vanillin and coumaric acid were diluted in DMSO to reach the final concentration of 5.21; $10.42 ; 20.83 ; 41.67 ; 83.33 ; 166.67(\mu \mathrm{g} / \mathrm{mL} ; \mu \mathrm{M})$.

The $\mathrm{IC}_{50}$ value for hyaluronidase inhibitory activity of OSE, vanillin, and coumaric acid based on $\mathrm{IC}_{50}$ value can be seen in Table 6 .

Table 6: $I C_{50}$ value hyaluronidase inhibitory activity of OSE, vanillin, and coumaric acid

\begin{tabular}{lcccc}
\hline Samples & Equation & $\mathbf{R}^{2}$ & $\mathrm{IC}_{50}(\mu \mathrm{M})$ & $\mathrm{IC}_{50}(\mu \mathrm{g} / \mathrm{mL})$ \\
\hline OSE & $\mathrm{y}=0.24 \mathrm{x}+0.34$ & 0.91 & - & 203.13 \\
Vanillin & $\mathrm{y}=0.15 \mathrm{x}+5.47$ & 0.99 & 297.33 & 45.23 \\
$\begin{array}{l}\text { Coumaric } \\
\text { Acid }\end{array}$ & $\mathrm{y}=0.89 \mathrm{x}+5.01$ & 0.94 & 50.11 & 8.21 \\
* & & & & \\
\hline
\end{tabular}

${ }^{*}$ Linear equations, coefficient of regression $\left(\mathrm{R}^{2}\right)$ and $\mathrm{IC}_{50}$ of each sample were calculated. $\mathrm{IC}_{50}$ of OSE was presented in $\mu \mathrm{g} / \mathrm{mL}$, while vanillin and coumaric acid were presented in $\mu \mathrm{M}$ and $\mu \mathrm{g} / \mathrm{mL}$.

Based on Figure 6, OSE showed the moderate activity with percentage $36.86 \pm 2.28 \%$ compared to coumaric acid $(48.48 \pm 0.40 \%)$ and vanillin $(20.84 \pm 4.78 \%)$. Coumaric acid has the lowest $\mathrm{IC}_{50}$ value $(8.22 \mu \mathrm{g} / \mathrm{mL})$ compared to OSE $(203.13 \mu \mathrm{g} / \mathrm{mL})$ and vanillin $(45.23 \mu \mathrm{g} / \mathrm{mL})$ (Table 6$)$. These results show OSE has low hyaluronidase inhibitory activity compared to vanillin and coumaric acid.

\section{Discussion}

Ayurveda, which means science of long life, is a 5,000-year-old system of Indian medicine (1500-1000 BC) designed to promote good health and longevity 
rather than to fight disease and was practiced by physicians and surgeons. Ayurveda usually recommends the use of several plant extracts in combination. Toxic effects of modern medicine are insufficient due to a lack of other components derived from the plants. Each herbal formulation contains multiple active compounds that may operate synergistically, producing therapeutic benefits and lowering the risks on adverse effects ${ }^{38}$. Rice (O. sativa), a herb belongs to Poaceae, has been known as a potential source of antioxidants in food, pharmaceutical and cosmetic industries. It has been utilized in the treatment of cancer and aging ${ }^{39}$. O. sativa has bioactive compounds, including many phenolic compounds as an antioxidant ${ }^{17}$. Five phenyl compounds isolated from the roots of $O$. sativa $\mathrm{L}$. are vanillin, methyl trans-ferulate, trans-p-coumaric acid methyl ester, N-benzoyltryptamine, and $\mathrm{N}$-(trans-cinnamoyl) tryptamine ${ }^{40}$. Phenols can be divided into two subgroups according to their structure, p-hydroxybenzoic acid derivatives such as gallic, protocatechuic and syringic acids, and hydroxycinnamic derivatives such as caffeic, ferulic, p-coumaric and chlorogenic acids ${ }^{19}$. The present study showed that OSE contained low phenols and triterpenoids, high terpenoids, and saponins. Phytochemical analysis of $O$. sativa was conducted in the previous study that showed $11-13 \%$ protein, approximately $11 \%$ fiber and $20 \%$ of its weight in oil, as well as functional compounds and antioxidants ${ }^{41}$. Phenolic compounds, such as benzoic or cinnamic acid derivatives, have been documented in Poaceae plants such as Sorghum $\mathrm{sp}^{42,43}$.

UV irradiation generates free radicals that can induce expression of certain members of the Matrix Metalloproteinase (MMP) family, which degrades collagen and other Extracellular Matrix (ECM) proteins that consist of the dermal connective tissue ${ }^{44}$. In this study, OSE had the lowest scavenging free radical activity as indicated by reduced ABTS and FRAP activities and DPPH scavenging activity compared to vanillin and coumaric acid. A recent study on $O$. sativa in different solvents showed that $O$. sativa ethanol extract have the lowest antioxidants $\left(\mathrm{IC}_{50}=4.78 \mu \mathrm{g} / \mathrm{mL}\right)$ compared to O. sativa methanol extract $\left(\mathrm{IC}_{50}=2.6 \mu \mathrm{g} / \mathrm{mL}\right)$ and $O$. sativa isopropanol extract $\left(\mathrm{IC}_{50}=2.4 \mu \mathrm{g} / \mathrm{mL}\right)^{45}$. O. sativa methanol and isopropanol extracts exhibited better free radical scavenging activity, which is associated with increasing phenolic compounds that increases antioxidant activity ${ }^{46}$. Coumaric acid has been reported to protect against oxidative stress and play a key role as an antioxidant and anti-inflammatory ${ }^{47,48}$. O. sativa oils such as coumaric acid and vanillin exhibited very good oxidative state with range oxidative stability 5.99-7.40 ${ }^{49}$.

OSE has the lowest DPPH scavenging activity compared to vanillin and coumaric acid, this data was not validated with previous study showed that $O$. sativa extract has rich secondary metabolites, especially alkaloids and phenolic acids that have strong antioxidant activity ${ }^{50}$. Phenolic and flavonoid contents are associated with strong antioxidant activity and especially in terms of DPPH and nitric oxide free radical scavenging ${ }^{51}$. The phenolic extracts from fermented O. sativa showed slow inhibition kinetics of the $\mathrm{DPPH}$ radical, as $\mathrm{IC}_{50}$ value obtained was $250 \mathrm{mg} / \mathrm{g}$ compared to unfermented $O$. sativa with value $213 \mathrm{mg} / \mathrm{g}$, while feluric acid 235.00 $\mathrm{mg} / \mathrm{g}^{52}$. In another study, Poaceae plants such as $Z$. mays ethanolic extract has low antioxidant activity with $\mathrm{IC}_{50}$ value of DPPH $163.45 \pm 6.34 \mu \mathrm{g} / \mathrm{mL}$, while T. aestivum bran ethanol extract $(0.5 \mathrm{mg} / \mathrm{kg})$ has DPPH value 58.00 $\pm 1.1 \%{ }^{53,54}$. T. aestivum methanol extract showed good radical scavengers with the inhibition of $12 \%$ at $1 \mathrm{~mL} /$ $\mathrm{mL}$ concentration ${ }^{55}$. T. aestivum has shown potential anti inflammatory, antioxidant, and anti aging properties ${ }^{56}$.

Collagen, elastin, and hyaluronic acid are the skin main components and have an important role in maintaining its structure and hydration ${ }^{57}$. These enzymes cause repetitive collagen fibers breakdown and responsible for structural defect in dermis and wrinkle development ${ }^{58}$. Collagenase and elastase contribute in production and degradation of these fibers, which is also induced by free radical oxidative stress ${ }^{59}$. In the present study, $O$. sativa had the lowest activity in collagenase inhibition compared to coumaric acid and vanillin. $O$. sativa has been studied in anti aging treatment. Watersoluble enzymatic extract from $O$. sativa served as a protective screen against UV-B radiation on cultivated keratinocytes and in vitro reconstructed $\operatorname{skin}^{60}$. In the other study, the extract of O. sativa plants callus improve the human-skin barrier function ${ }^{61}$. Mechanisms of anti aging are via up-regulation of collagen sythesis in normal human dermal fibroblast and down-regulation of matrix metalloproteinase ${ }^{62}$. Vanillin content was also reported to inhibit matrix metalloproteinase- 9 expression through 
down-regulation of nuclear factor-kB signaling pathway in human hepatocellular carcinoma cells ${ }^{63}$.

Elastin is a fibrose protein that compose $2-4 \%$ of the ECM and involved in the hydration of the skin ${ }^{64}$. Elastase is responsible for increased tissue permeability, inflammation progress and delayed wound healing ${ }^{65}$. Elastase is also the key enzyme that attacks all the major connective tissue matrix protein ${ }^{66}$. In elastase assay, OSE showed the lowest activity compared to coumaric acid and vanillin. Low activity of OSE in the present study might be due to low content of phenol and absence of flavonoids in phytochemical screening. Several studies showed that phenol and flavonoid content of O. sativa possess anti-elastase activity ${ }^{51,67,68}$. However, vanillin has the highest elastase inhibitory activity.

Our present study showed that OSE had the lowest hyaluronidase inhibitory activity compared to CA and vanillin. These results might be correlated with an absence of tannin in OSE. Tannin-rich plants have been reported to inhibit hyaluronidase and elastase release from stimulated neutrophils in vitro ${ }^{69}$. Hyaluronidase (Haases) selectively degrade Hyaluronic Acid (HA), which is a megadalton acidic structural polysaccharide found exclusively in the Extracellular Matrix (ECM). Haase inhibitors are thus potent regulators that maintain HA homeostasis and they might serve as antiinflammatory, anti aging, antimicrobial, anticancer and antitoxin and contraceptive agents ${ }^{70}$. Hyaluronidase degrades hyaluronic acid by lowering its viscosity and increasing the permeability ${ }^{71}$.

\section{Conclusion}

Vanillin and coumaric acid have higher antioxidant activity through DPPH scavenging, ABTS-reducing activities and FRAP, and anti-aging through inhibitory activity of collagenase, elastase and hyaluronidase than O. sativa extract.

\section{Acknowledgment}

This research was supported by Biomolecular and Biomedical Research Center, Aretha Medika Utama, Bandung, Indonesia for a research grant, laboratory facilities, and research methodology. We are thankful to Neng Sri Mulkiyatul M. A, Kartiko Adi Poerbo and
Muhammad BiharJafarian as the interns at Biomolecular and Biomedical Research Center, Aretha Medika Utama, Bandung, Indonesia for their valuable assistance.

\section{References}

1. Rattan SIS, Sodagam L. Gerontomodulatory and youthpreserving effects of zeatin on human skin fibroblasts undergoing aging in vitro. Rejuvenation Res. 2005; $8(1): 46-57$.

2. Kim DW, Hwang I, Kim D. Coenzyme Q10 effects on manganese superoxide dismutase and glutathione peroxidase in the hairless mouse skin induced by ultraviolet b irradiation. Bio Factors. 2007; 30(3):139-47.

3. Berneburg M, Plattenberg H, Medve-Konig K, Pfahlberg A, Gers-Barlag $\mathrm{H}$, Gefeller $\mathrm{O}$, et al. Induction of the photoaging-associated mitochondrial common deletion in vivo in normal human skin. J Invest Dermatol. 2004; 122(5):1277-83.

4. Yaar M, Eller MS, Gilchrest BA. Fifty years of skin aging. J Investig Dermatol Symp Proc. 2002; 7(1):51-8.

5. Demina N, Lysenko S. Collagenolytic enzymes synthesized by microorganisms. Mikrobiologiia. 1996; 65:293-304.

6. Pogrel M, Lowe M, Stern R. Hyaluronan (hyaluronic acid) in human saliva. Arch Oral Biol. 1996; 41(7):667-71.

7. Thring TS, Hili P, Naughton DP. Anti-collagenase,antielastase and anti-oxidant activities of extracts from 21 plants. BMC Compl Alter Med. 2009; 9(27):1-11.

8. Longo V, Finch C. Evolutionary medicine: From dwarf model systems to healthy centenarians? Sci. 2003; 299:1342-6.

9. Makrantonaki E, Brink T, Zampeli V, Elewa R, Mlody B, Hossini A. Identification of biomarkers of human skin ageing in both genders. Wnt signalling- a label of skin ageing? PLos ONE. 2010; 7(11).

10. Ndlovu G, Fouche G, Tselanyane M, Cordier W, Steenkamp V. In vitro determination of the anti-aging potential of four Southern African medicinal plants. BMC Complement Atern Med. 2013; 13(304):1-7.

11. Yasui H, Sakurai H. Chemiluminescent detection and imaging of reactive oxygen species in live mouse skin exposed to UVA. Biochem Biophys Res Commun. 2000; 269(1):131-6.

12. Kim H, Yun J, Lee J, Hong H, Jeong J, Kim E, et al. SUMO1 attenuates stress-induced ROS generation by inhibiting NADPH oxidase 2. Biochem Biophys Res Commun. 2011; 410(3):555-62. 
13. Mruka D, Silvestrini B, Mo My, Cheng C. Antioxidant superoxide dismutase- A review, its function, regulation in the testis, and role in male fertility. Contracept. 2002; 65:305-11.

14. Moini H, Packer L, Saris N. Antioxidant and prooxidant activities of alpha-lipoic acid and dihydrolipoic acid. Toxicol Appl Pharmacol. 2002; 182(1):84-90.

15. Cai Y, Luo Q, Sun M, Corke H. Antioxidant activity and phenolic compounds of 112 traditional Chinese medicinal plants associated with anticancer. Life Sci. 2004; 74(17):2157-84.

16. Kaur C, Kapoor H. Anti-oxidant activity and total phenolic content of some Asian vegetables. Int J Food Sci Technol. 2002; 37(2):153-61.

17. Mira N, Barros R, Schiocchet M, Noldin J, Lanfer-Marquez $\mathrm{U}$. Extraction, analysis and distribution of phenolic acids in pigmented and non-pigmented genotypes of rice (Oryza sativa L.). Clencia e Tecnologia de Alimentos. 2008; 28:994-1002.

18. Pourali O, Asghari FS, Yoshida H. Production of phenolic compounds from rice bran biomass under subcritical water conditions. Chem Eng J. 2010; 160(1):259-66.

19. Martins S, Mussatto S, Martinez-Avila G, Montanez-Saenz J, Aguilar C, Teixeira J. Bioactive phenolic compounds: production and extraction by solid-state fermentation. Biotechnol Adv. 2011; 29:365-73.

20. Yang HJ, Yue Q, Cao YC, Zhang DF, Wang JQ. Effects of crude feruloyl and acetyl esterase solutions of Neocallimastix sp. YQ1 and Anaeromyces sp. YQ3 isolated from holstein steers on hydrolysis of chinese wild rye grasshay, wheat bran, maize bran, wheat straw and corn stalks. Anim Feed Sci Technol. 2009; 154:218-27.

21. Kilic I, Yesiloglu Y. Spectroscopic studies on the antioxidant activity of p-coumaric acid. Biomol Spectrosc. 2013; 115:719-24.

22. Widowati W, Wijaya L, Wargasetia T, Bachtiar I, Yellianty Y, Laksmitawati D. Antioxidant, anticancer, and apoptosisinducing effects of piper extracts in hela cells. J Exp Integr Med. 2013; 3(3):225-30.

23. Widowati W, Ratnawati $H$, Rusdi U, Winarno W, Imanuel V. Phytochemical assay and antiplatelet activity of fractions of velvet been seeds (Mucuna pruriens). HAYATI J Biosci. 2010; 17(2):85-90.

24. Bera T, Chatterjee K, Ghosh D. In vitro antioxidant properties of the hydro-methanol extract of the seeds of Switenia mahagoni (L.) Jacq. BGM. 2015; 7(1):18-24.

25. Adnyana I, Abuzaid A, Iskandar E, Kurniati N. Pancreatic lipase and a-amylase inhibitory potential of mangosteen
(Garcinia mangostana Linn.) pericarp extract. Int J Med Res Health Sci. 2016; 5(1):23-8.

26. Widowati W, Maesaroh M, Fauziah N, Erawijantari PP, Sandra F. Free radical scavenging and a-/b-glucosidase inhibitory activities of rambutan (Nephelium lappaceum L.) peel extract. Indones Biomed J. 2015; 7(3):157-62.

27. Sohn D, Kim Y, Oh S, Park E, Li X, Lee B. Hepatoprotective and free radical scavenging effects of Nelumbo nucifera. Phytomed. 2003; 10(2-3):165-9.

28. Widowati W. Green tea extract protects endothelial progenitor cells from oxidative insult through reduction of intracellular reactive oxygen species activity. J Basic Med Sci. 2014; 17(9):702-9.

29. Etoundi C, Kuat D, Ngondi J, Oben J. Anti-amylase Antilipase and antioxidant effects of aqueous extracts of some cameroonian spices. J Nat Products. 2010; 3:165-71.

30. Mishra A, Bapat M, Tilak J, Devasagayam T. Antioxidant activity of Garcinia indica (kokam) and its syrup. Curr Sci. 2006; 91:90-3.

31. Tu P, Tawata S. Antioxidant, antiaging, and antimelanogenic properties of the essential oil from two varieties of Alpinia zerumbet. Molecules. 2015; 20:1672340.

32. Kumar S, Sandhir R, Ojha S. Evaluation of antioxidant activity and total phenol in different varieties of Lantana camara leaves. BMC Res Notes. 2014; 7(560):1-9.

33. Widowati W, Ratnawati H, Husin W, Maesaroh $M$. Antioxidant properties of spice extracts. Biomed Eng. 2015; 1(1):24-9.

34. Miller NJ, Rice-Evans CA. Factors influencing the antioxidant activity determined by the ABTS+ radical cation assay. Free Radical Res. 1997; 26:195-9.

35. Antolovich M, Prenzler PD, Patsalides E, McDonald S, Robards K. Methods for testing antioxidant activity. Analyst. 2002; 127:183-98.

36. Sumantran VN, Kulkarni AA, Harsulkar A, Wele A, Koppikar SJ, Chandwaskar R, et al. Hyaluronidase and collagenase inhibitory activities of the herbal formulation Triphala guggulu. J Biosci. 2007; 32(4):755-61.

37. Tung JS, Mark GE, Hollis GF. A microplate assay for hyaluronidase and hyaluronidase inhibitors. Anal Biochem. 1994; 223:149-52.

38. Garodia P, Ichikawa H, Malani N, Sethi G, Aggarwal BB. From ancient medicine to modern medicine: Ayurvedic concepts of health and their role in inflammation and cancer. J Soc Integr Oncol. 2007 Mar 21; 5(1):25-37. 
39. Iqbal S, Bhanger M, Anwar F. Antioxidant properties and components of some commercially available varieties of rice bran in Pakistan. Food Chem. 2005; 93:265-72.

40. Cho JG, Huh J, Jeong RH, Baek NI. Inhibition effect of phenyl compounds from the Oryza sativaroots on melanin production in mMne B16-F10 melanoma cells. Nat Prod Res. 2014; 29(11):1-3.

41. Oliveira M, Feddern V, Kupski L, Cipolatti E, BadialeFurlong E, Souza-Soares L. Changes in lipid, fatty acids and phospolipids composition of whole rice bran after solid-state fungal fermentation. Bioresour Technol. 2011; 102:8335-8.

42. Awika J, Rooney L. Sorghum phytochemicals and their potential impact on human health. Phytochem. 2004; 65:1199-221.

43. Dykes L, Rooney L. Sorghum and millet phenols and antioxidants. J Cer Sci. 2006; 44:236-51.

44. Quan T, Qin Z, Xia W, Shao Y, Voorhees J, Fisher GJ. Matrix-degrading metalloproteinases in photoaging. J Investig. 2009; 14(1):20-4.

45. Zubair M, Anwar F, Shahid SA. Effect of extraction solvents on phenolics and antioxidant activity of selected varieties of pakistani rice (Oryza sativa). Int J Agric Biol. 2012; 14:935-40.

46. Roginsky V, Lissi EA. Review of methods to determine chain breaking antioxidant activity in food. Food Chem. 2005; 92:235-54.

47. Ferguson L, Zhu S, Harris P. Antioxidant and antigenotoxic effects of plant cell wall hydroxycinnamic acids in cultured HT-29 cells. Mol Nutr Food Res. 2005; 49:585-93.

48. Svobodova A, Psotova J, Walterova D. Natural phenolics in the prevention ov UV-induced skin damage. Biomed Papers. 2003; 147(2):137-45.

49. Anwar F, Bhanger M, Kazi T. Relationships of rancimat and AOM values at varying temperatures for several oils and fats. J Am Oil Chem Sci. 2003; 80:151-5.

50. Chung HS, Shin JC. Characterization of antioxidant alkaloids and phenolic acids from anthocyanin-pigmented rice (Oryza sativa cv. Heugjinjubyeo). Food Chem. 2007; 104:1670-7.

51. Karimi E, Mehrabanjoubani P, Keshavarzian M, Oskouelan E, Jaafar HZ, Abdolzadeh A. Identification and quantification of phenolic and flavonoid components in straw and seed husk of some rice varieties (Oryza sativa L.) and their antioxidant properties. J Sci Food Agric. 2014; 94:2324-30.

52. Schmidt CG, Goncalves LM, Prietto L, Hackbart HS, Furlong EB. Antioxidant activity and enzyme inhibition of phenolic acids from fermented rice bran with fungus Rhizopus oryzae. Food Chem. 2014; 146:371-7.

53. Liyana-Pathirana CM, Shahidi F. Antioxidant properties of commercial soft and hard winter wheats (Triticum aestivium L.) and their milling fractions. J Sci Food Agric. 2006; 86:477-85.

54. Liu J, Wang C, Wang Z, Zhang C, Lu S, Liu J. The antioxidant and free-radical scavenging activities of extract and fractions from corn silk (Zea mays L.) and related flavone glycosides. Food Chem. 2011; 126:261-9.

55. Arya P, Kumar M. Chemoprevention by Triticum aestivum of mouse skin carcinogenesis induced by DMBA and croton oil-association with oxidative status. Asian Pacific J Cancer Prev. 2011; 12(12):143-8.

56. Smith B. Generalization of spatially variant apodization to nonintegral nyquist sampling rats. IEEE Trans Image Process. 2000; 9:1088-93.

57. Hooda R. Antiwrinkle herbal drugs-an update. J Pharmacog Phytochem. 2015; 4(4):277-81.

58. Shehada A. A review on natural bioactive compounds as potential antiwrinkle agents. World J Pharm. 2014; 3:52844.

59. Mukherjee P, Maity N, Nema N, Sarkar B. Bioactive compounds from natural resources against skin aging. Phytomed. 2011; 19:64-73.

60. Santa-Maria C, Revilla E, Miramontes E, Bautista J, Garcinia-Martinez A, Romero E, et al. Protection against free radicals (UVB irradiation) of a water-soluble enzymatic extract from rice bran. study using human keratinocyte monolayer and reconstructed human epidermis. Food Chem Toxicol. 2010; 48(1):83-8.

61. Ludwig P, Bennets S, Gruber J. Rice meristem stimulates epigenetic rejuvenation: New technologies. S Afr Pharm Cosmet Rev. 2011; 38:34-7.

62. Mitra R. Medicinal plants of Indonesia. Asia Pac Biotech News. 2007; 11:727-35.

63. Liang JA, Wu SL, Lo HY, Hsiang CY, Ho TY. Vanillin inhibits matrix metalloproteinase- 9 expression through down-regulation of nuclear factor-kb signaling pathway in human hepatocellular carcinoma cells. Mol Pharmacol. 2009; 75(1):151-7.

64. Jenkins G. Molecular mechanisms of skin ageing. Mech Ageing Dev. 2002; 123:801-810.

65. Siedle B, Hrenn A, Merfort I. Natural compounds as inhibitors of human neutrophil elastase. Planta Med. 2007; 73:401-20.

66. Azmi N, Hashim P, Hashim DM, Halimoon N, Nik Majid NM. Anti-elastase, anti-tyrosinase and matrix 
metalloproteinase-1 inhibitory activity of earthworm extracts as potential new anti-aging agent. Asian Pac J Trop Biomed. 2014; 4(1):348-52.

67. Hrenn A, Steinbrecher T, Labahn A, Schwager J, Schempp C, Merfort I. Plant phenolics inhibit neutrophil elastase. Planta Med. 2006; 72:1127-31.

68. Kanashiro A, Souza J, Kabeya L, Azzolini A, LucisanoValim Y. Elastase release by stimulated neutrophils inhibited by flavonoids: Importance of the catechol group. Z Naturforsch C. 2007; 62(5-6):357-61.

69. Piwowarski J, Kiss AK, Kozlowska-Wojciechowska M. Anti-hyaluronidase and anti-elastase activity screening of tannin-rich plant material used in traditional polish medicine for external treatment of diseases with inflammatory background. J Ethnopharmacol. 2011; 137:937-41.

70. Girish K, Kemparaju K, Nagaraju S, Vishwanath B. Hyaluronidase inhibitors: A biological and therapeutic perspective. Curr Med Chem. 2009; 16:2261-88.

71. Girish K, Kemparaju K. The Magic Glue Hyaluronan its Eraser Hyaluronidase: A biological overview. Sci. 2007; 80:1921-43. 